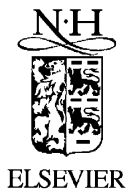

Available online at www.sciencedirect.com

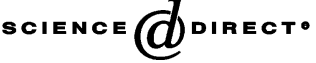

Journal of Financial Economics 71 (2004) 489-516

www.elsevier.com/locate/econbase

\title{
Internal capital markets and investment policy: evidence from corporate spinoffs
}

\author{
Seoungpil Ahn ${ }^{\mathrm{a}}$, David J. Denis ${ }^{\mathrm{b}, *}$ \\ a The John Molson School of Business, Concordia University, Montreal, QC, Canada H3G 1 M8 \\ ${ }^{\mathrm{b}}$ Krannert Graduate School of Management, Purdue University, West Lafayette, IN 47907, USA
}

Received 15 February 2002; accepted 17 February 2003

\begin{abstract}
We analyze changes in investment policy following 106 spinoffs between 1981 and 1996. Pre-spinoff, the sample firms are valued at a discount and invest less in their high $q$ segments than do their single-segment peers. Post-spinoff, there is a significant increase in measures of investment efficiency and the diversification discount is eliminated. Furthermore, changes in excess value around the spinoff are positively related to changes in measures of investment efficiency. These findings support the view that (i) diversified firms allocate investment funds inefficiently, and (ii) by breaking up the conglomerate, spinoffs create value by improving investment efficiency.
\end{abstract}

(C) 2003 Elsevier B.V. All rights reserved.

JEL classification: G31; G32; G34

Keywords: Internal capital markets; Spinoffs; Diversification

\section{Introduction}

A large number of academic studies report that diversified firms are valued at a discount relative to portfolios of single-segment firms operating in the same industries. This diversification discount is fairly robust over time and exists both in

\footnotetext{
${ }^{2}$ We thank Diane Denis, Tim Kruse, John McConnell, Gordon Phillips, Raghu Rau, an anonymous referee, and seminar participants at DePaul University, Penn State University, Rutgers University, and the University of Arkansas for helpful comments.

*Corresponding author. Tel.: + 1-765-494-4434; fax: + 1-765-494-9658.

E-mail address: daviddenis@mgmt.purdue.edu (D.J. Denis).
} 
the U.S. and in other developed economies. ${ }^{1}$ Further, Comment and Jarrell (1995) show a systematic pattern of refocusing among U.S. firms since the mid-1980s. On average, this refocusing is associated with significant increases in shareholder wealth. Announcements of focus-increasing transactions such as asset sales, equity carveouts, and corporate spinoffs are all met with positive stock price reactions. ${ }^{2}$

Although the existence of the diversification discount is not questioned, its interpretation remains controversial. Some argue that the evidence supports the view that diversified organizations destroy value. A particular version of this hypothesis is that diversified firms invest inefficiently, investing too much in some business units and/or too little in others. This hypothesis draws theoretical support from the models of Rajan et al. (2000) and Scharfstein and Stein (2000) and is consistent with the evidence in Scharfstein (1998) and Rajan et al. (2000). However, both Chevalier (2000) and Whited (2001) argue that the empirical results supporting the inefficient investment hypothesis can be explained by measurement error. In addition, studies by Campa and Kedia (1999), Graham et al. (2002), and Maksimovic and Phillips (2002) argue that the link between diversification and value is not causal, but rather is the result of endogenous firm choices.

We provide evidence on the inefficient investment hypothesis by analyzing changes in investment policy following corporate spinoffs. If the diversification discount is caused in part by inefficient investment policies in diversified firms, we expect that (i) the breakup of the diversified firm will significantly reduce the discount, (ii) diversified firms will invest inefficiently prior to a breakup but increase investment efficiency following the breakup, and (iii) the increase in value following the breakup will be positively related to changes in measures of investment efficiency.

Using a sample of 106 spinoffs completed by multisegment firms between 1981 and 1996, we report results that are broadly consistent with the inefficient investment hypothesis. Like previous studies of diversified firms, we find that prior to the spinoff, the sample firms trade at a significant discount to stand-alone firms. Following the spinoff, however, the diversification discount is eliminated.

We conduct several tests to determine whether a change in investment efficiency contributes to the change in value following the spinoff. First, we examine industryadjusted levels of investment in individual segments. We find that prior to the spinoff, industry-adjusted investment is negative in the firm's high- $q$ segments and statistically insignificant in the firm's low- $q$ segments. Industry-adjusted investment is significantly higher in the firm's low- $q$ segments than in its high- $q$ segments. Following the spinoff, investment in high- $q$ segments is significantly increased.

Second, we compute two measures of firm-level investment efficiency, the relative investment ratio (RINV) and Rajan et al.'s (2000) relative value-added (RVA)

\footnotetext{
${ }^{1}$ See Lang and Stulz (1994), Berger and Ofek (1995), and Servaes (1996) for evidence on the diversification discount in U.S. firms, and Lins and Servaes (1999) for international evidence.

${ }^{2}$ See, among others, Lang et al. (1994), John and Ofek (1995), and Dittmar and Shivdasani (2003) for evidence on the stock price reaction to divestiture announcements; Allen and McConnell (1998) for evidence on the stock price reaction to equity carve-outs; and, Hite and Owers (1983), Schipper and Smith (1983), Miles and Rosenfeld (1983), Vijh (1994), Allen et al. (1995), and Daley et al. (1997) for evidence on the stock price reaction to spinoffs.
} 
measure. Positive values for each measure indicate that the firm invests relatively more in its high- $q$ segments than in its low- $q$ segments. We find that the sample firms exhibit significantly negative values of RINV and RVA prior to the spinoff, and a substantial deterioration in both RINV and RVA in the three years prior to the spinoff. Following the spinoff, both RINV and RVA are significantly increased and are insignificantly different from zero. These changes in RVA and RINV are largest for those firms that have the greatest dispersion in segment $q$ values in the year prior to the spinoff. Further tests indicate that the changes in investment allocations are not due to an unexpected improvement in the growth opportunities of high- $q$ segments that is not captured by the $q$ of single-segment industry peers.

Finally, we examine the link between changes in value and changes in investment efficiency. Controlling for changes in cash flows and changes in investment levels, we find that the change in excess value from the year prior to the spinoff to the year following the spinoff is positively related to the change in either RINV or RVA over the same period. Taken together, these findings imply that the sample firms invest inefficiently prior to the spinoff and significantly improve investment efficiency following the spinoff. This increase in investment efficiency leads to a corresponding increase in firm value.

Nevertheless, our point estimates suggest that it is unlikely that changes in investment policy can account for the entire increase in firm value surrounding spinoffs. Other potential explanations include wealth transfers from bondholders (Hite and Owers, 1983; Parrino, 1997), tax and regulatory benefits (Schipper and Smith, 1983), the facilitation of corporate control transactions (Cusatis et al., 1993), the reversal of prior takeover losses (Allen et al., 1995), improved contracting efficiency (Hite and Owers, 1983; Schipper and Smith, 1983; Aron, 1991), enhanced corporate focus (Daley et al., 1997), and reduced information asymmetry (Gilson et al., 1997; Krishnaswami and Subramaniam, 1999). As we discuss later, these other explanations are not necessarily mutually exclusive with the inefficient investment hypothesis.

The remainder of the paper is organized as follows. In Section 2, we describe our research design in more detail. In Section 3, we describe the sample selection procedure and provide descriptive statistics for the sample spinoffs. Sections 4-6 contain our main analysis of changes in excess value and changes investment policy. Section 7 provides a discussion of our results and offers possible explanations for the observed changes in investment policy. Section 8 concludes.

\section{Research design}

Our experimental design analyzes changes in investment policy following the breakup of a conglomerate. In doing so, we aim to minimize the importance of problems in the measurement of segment-level growth opportunities. Prior studies test for a causal link between diversification and value by reporting differences in capital allocations between diversified and single-segment firms. For example, both Lamont (1997) and Shin and Stulz (1998) report evidence that investment in 
segments of diversified firms is affected by the cash flows of other segments within the firm. This implies that diversified firms actively reallocate capital across the firm's business segments. Moreover, as noted earlier, both Rajan et al. (2000) and Scharfstein (1998) argue that this reallocation is inefficient since diversified firms do not appear to reallocate capital to the divisions with the best investment opportunities.

Although these findings are consistent with the inefficient investment hypothesis, the results in Chevalier (2000) and Whited (2001) cast doubt on this interpretation. Both studies note that segment-level growth opportunities are typically estimated using the median Tobin's $q$ for single-segment firms operating within the same industry. Whited (2001) shows that the noise in the estimate of segment $Q$ can account for evidence of capital reallocations of the type reported in Shin and Stulz (1998). Moreover, Chevalier (2000) reports that the investment patterns that the literature has ascribed to cross-subsidization between divisions of diversified firms are evident in pairs of firms prior to the time that they combine through merger. She argues, therefore, that at least some of the evidence of inefficient investment in diversified firms is due to systematic differences between the segments of diversified firms and single-segment firms.

Our tests examine changes in investment allocations across the same set of business units over time. In one period, the units are part of a diversified firm, whereas in the second period a unit has been spun off. Given this experimental design, it is difficult to attribute our findings to the type of measurement error problem described in Chevalier (2000) and Whited (2001). If there is measurement error in the estimate of segment $q$, that error is presumably present in both the prespinoff and post-spinoff periods. Consistent with the literature, we estimate these segment $q$ values as the median $q$ of single-segment companies operating in the same three-digit SIC industry. However, we later show that our findings are robust to alternative measures of the marginal $q$ of segment investment.

Although conglomerates can be broken up in several ways, including spinoffs, divestitures, and equity carve-outs, we believe that spinoffs are the best candidate for the study of the effects of internal capital markets. In a spinoff, a parent company distributes some or all of its equity ownership in a subsidiary as a pro rata dividend (usually tax-free) to the company's shareholders. Thus, unlike divestitures, both the spunoff entity and the parent company are independent companies following the spinoff. This allows us to analyze financial data for the parent and the spunoff unit both before the spinoff (i.e., as a conglomerate) and after completion of the spinoff. Indeed, an important feature of our experimental design is that we combine the data of the spunoff unit and the parent following the spinoff so as to analyze the post-spinoff investment policy as if the firm were still a conglomerate. Additionally, unlike divestitures and carve-outs, spinoffs do not involve any cash inflows, changes in ownership, or asset revaluations at the time of the breakup. Thus, changes in investment policy following the spinoff are less likely to be caused by changes in financial resources, incentives from equity ownership, or measurement error due to the standardization of investment by asset value. 
Nonetheless, there are two caveats to our research design. First, by focusing on events in which conglomerates are broken up, we might bias our sample towards those situations in which investment inefficiencies are most severe. Hence, our ability to generalize our findings to the population of diversified firms is potentially limited. Second, our analysis assumes that any observed changes in investment policy can be attributed to the elimination of inefficient internal capital markets. It is possible, however, that other changes are taking place that also affect investment policies. Palia and Ye (2002) report that the extent to which diversified firms misallocate divisional investment is reduced when division managers have a higher proportion of shares in options. A spinoff might allow for recontracting that better aligns managerial incentives with those of shareholders.

Our empirical approach complements that of Dittmar and Shivdasani (2003) and Gertner et al. (2002). Dittmar and Shivdasani (2003) examine how the divestiture of a division affects investment in the parent firm's remaining divisions. Gertner et al. (2002) examine changes in the investment behavior of divisions that are spun off from their corporate parent. Rather than focusing only on the parent or the spunoff subsidiary, our study examines changes in investment policy for the combined firm. This allows us to capture the total impact of the spinoff on investment policy. This is important if, for example, a change in investment in the parent firm is offset by changes in the spunoff unit, or vice versa. As an example, consider a firm exhibiting suboptimal investment behavior because of a debt overhang problem. The firm could spin off a unit and keep a disproportionate share of the firm's debt in the remaining parent. (See, for example, Parrino's (1997) analysis of the Marriott spinoff.) This would constrain investment in the parent, but reduce financial constraints for the spunoff unit. It is not immediately obvious whether the net impact of the spinoff would be to increase or decrease investment efficiency.

\section{Sample selection and descriptive statistics}

Our initial sample is drawn from the Security Data Corporation's (SDC) Mergers and Acquisitions Database and the daily returns file of the Center for Research in Security Prices (CRSP). From these data sources, we identify all spinoffs between 1981 and 1996. We confirm that each transaction is indeed a spinoff (rather than a divestiture or carve-out) by examining descriptions of the transaction reported in Dow Jones Interactive (DJI). We also limit the sample to tax-free spinoffs, as identified by the $\mathrm{CCH}$ Capital Change Reports. According to Section 335 of the Internal Revenue Code, to be eligible for tax-exempt status, (1) a parent firm must distribute at least $80 \%$ of the outstanding shares of a subsidiary to its existing shareholders and any shares retained by the parent firm must not constitute practical control of the subsidiary, (2) the separating subsidiary should have been in active operation for at least five years and have been owned, directly or indirectly, by the parent firm for at least five years, and (3) the parent firm and the separated subsidiary should each be engaged in the active conduct of a trade or business immediately after the distribution. 
This process leaves us with 219 completed tax-free spinoffs over the sample period. After further restricting the sample to firms that have financial data on Compustat at both the firm level and the business segment level, and excluding firms with segments operating in the financial industry (SIC 6000-6999), we are left with a final sample of 150 spinoffs.

Table 1 presents the time profile of the sample spinoffs. There are few spinoffs in the early 1980s and a modest clustering in the mid-1990s. Outside of these two extremes, the sample is fairly uniform over time. Of the 150 sample spinoffs, 106 $(71 \%)$ are undertaken by firms with multiple business segments as listed on Compustat's Industry Segment Files and 44 (29\%) are undertaken by single-segment firms.

In Table 2, we report descriptive statistics for the sample firms, the relative size of the spinoff, and the stock price reaction to the spinoff announcement. All firm characteristics are measured as of the fiscal year-end prior to the spinoff announcement. Not surprisingly, the firms operating in multiple industries are significantly larger than the single-segment firms. However, multisegment and singlesegment firms are quite similar with respect to leverage ratios, profitability, and investment rates. Consistent with Lang and Stulz (1994), the multisegment firms have lower Tobin's $q$ ratios than the single-segment firms.

We measure the relative size of the sample spinoffs as the ratio of the market value of the spunoff unit's equity to the combined market value of the equity of the spunoff unit and the parent firm as of the first trading day following the spinoff. On average, the sample spinoffs represent $25 \%$ of the combined firm. The relative size of the spunoff unit is approximately equal in spinoffs of multisegment and singlesegment firms.

Table 1

Time profile of sample spinoffs

The initial sample of spinoffs is collected from Security Data Corporation (SDC) M\&A Database and the CRSP File from 1981 to 1996. After excluding taxable transactions, there are 219 completed tax-free spinoffs over the sample period. The sample is restricted to those firms with financial data on COMPUSTAT at the firm level and the segment level. The firms should not have reported segments operating in the financial sector (SIC 6000-6999). After the selection process, the final sample consists of 150 spinoffs. The sample is partitioned on the basis of whether the firm reports multiple business segments or just a single business segment on the COMPUSTAT Industry Segment File.

\begin{tabular}{lrcccccc}
\hline Year & $N$ & Multi-segment & Single-segment & Year & $N$ & Multi-segment & Single-segment \\
\hline 1981 & 2 & 0 & 2 & 1989 & 6 & 5 & 1 \\
1982 & 4 & 3 & 1 & 1990 & 8 & 6 & 2 \\
1983 & 3 & 2 & 1 & 1991 & 5 & 4 & 1 \\
1984 & 9 & 8 & 1 & 1992 & 9 & 5 & 4 \\
1985 & 11 & 8 & 3 & 1993 & 12 & 9 & 4 \\
1986 & 12 & 10 & 2 & 1994 & 14 & 10 & 6 \\
1987 & 9 & 5 & 4 & 1995 & 14 & 8 & 7 \\
1988 & 12 & 10 & 2 & 1996 & 20 & 13 & 44 \\
& & & & & & \\
\end{tabular}


Table 2

Descriptive statistics

Summary statistics for selected financial characteristics, the relative size of the spinoff, and the stock price reaction to the spinoff announcement. Means are reported above medians. All financial characteristics are obtained from COMPUSTAT, are expressed in millions of dollars, and are measured as of the fiscal yearend just prior to the spinoff announcement year (Year -1$)$. Tobin's $q$ is measured with the method of Badrinath and Lewellen (1997). The relative size of the distribution is the market value of the spunoff unit divided by the sum of the market values of the remaining parent and the spunoff unit. Market value of the firm is the book value of assets plus the market value of common equity less the book value of equity less deferred tax. Cumulative market-adjusted returns (MARs) are measured over the three days centered on the spinoff announcement. $*, * *$, and $* * *$ indicate that the difference between multi- and single-segment spinoffs is statistically significant at the $10 \%, 5 \%$, and $1 \%$ levels, respectively.

\begin{tabular}{lccc}
\hline Characteristic & $\begin{array}{c}\text { Full sample } \\
(N=150)\end{array}$ & $\begin{array}{c}\text { Multisegment firms } \\
(N=106)\end{array}$ & $\begin{array}{c}\text { Single-segment firms } \\
(N=44)\end{array}$ \\
\hline Book value of total assets & 2826.00 & $3330.19^{*}$ & 1870.65 \\
& {$[724.76]$} & {$[1243.76]^{* * *}$} & {$[221.18]$} \\
Sales revenue & 2695.25 & $3252.13^{* * *}$ & 1379.00 \\
& {$[809.95]$} & {$[1380.44]^{* * *}$} & {$[348.72]$} \\
Total debt/total assets & 0.2796 & 0.2768 & 0.2847 \\
& {$[0.2541]$} & {$[0.2509]$} & {$[0.2652]$} \\
Operating income/sales & 0.1551 & 0.1476 & 0.1732 \\
& {$[0.1368]$} & {$[0.1344]$} & {$[0.1497]$} \\
Capital expenditures/total assets & 0.0749 & 0.0754 & 0.0738 \\
& {$[0.0577]$} & {$[0.0619]$} & {$[0.0521]$} \\
Tobin's $q$ & 1.3916 & $1.2980^{* * *}$ & 1.6165 \\
& {$[1.2372]$} & {$[1.1976]^{* *}$} & {$[1.3407]$} \\
Relative size of distribution & 0.2546 & 0.2615 & 0.2379 \\
& {$[0.1700]$} & {$[0.1600]$} & {$[0.1700]$} \\
MAR $(-1,+1)$ & $4.03 \%$ & $3.29 \% *$ & $5.77 \%$ \\
& {$[3.15 \%]$} & {$[3.06 \%]$} & {$[3.54 \%]$} \\
\hline
\end{tabular}

Finally, we measure the stock price reaction to the announcement of the sample spinoffs. We identify the earliest announcement of the spinoff using the SDC database and the DJI database. In most cases, the announcement dates from SDC and DJI coincide. When there is a discrepancy, we use the earlier date as the announcement date for our analysis. We sum daily market-adjusted returns over the three days centered on the announcement date $(-1,+1)$. Similar to others (see the studies cited in footnote \#2), we find that spinoff announcements are met with a positive stock price reaction. Three-day cumulative market-adjusted returns (MARs) average $4.03 \%$ for the full sample, $3.29 \%$ for the multisegment firms, and $5.77 \%$ for the single-segment firms. We obtain nearly identical results if we measure the stock 
price reaction using the market model technique with parameters estimated over days -263 to -11 relative to the announcement date.

Because our primary tests require data on investment expenditures at the segment level, the remainder of our analysis is conducted on the 106 spinoffs by multisegment firms. Among these firms, the median firm reports three segments prior to the spinoff and two segments following the spinoff (these and the following data are not reported in Table 2). Similarly, the median firm operates in three distinct three-digit SIC industries prior to the spinoff and one three-digit SIC industry following the spinoff. Using continuous measures of diversity, we find a similar increase in company focus following the spinoff. For example, the within-firm standard deviation of industry Tobin's $q$ declines from a median of 0.29 prior to the spinoff to 0.01 following the spinoff, while the median sales-based Herfindahl index increases from 0.50 to 0.82 . Both of these changes are statistically significant at the 0.01 level. The bottom-line is that the parent firms become considerably more focused following the sample spinoffs.

It is also interesting to note that although the spinoffs appear to separate the firm's higher $q$ segments from the lower- $q$ segments (as evidenced by the large reduction in the standard deviation of within-firm industry $q$ 's), there is no systematic pattern as to which type of segment is spun off. It is equally likely that the spunoff unit has an industry $q$ above the firm's sales-weighted median as it is that the spunoff unit has a below-median $q$.

\section{Changes in excess value}

If the widely documented diversification discount is caused in part by inefficient investment policies in diversified firms, we expect to observe a significant reduction in the discount following the breakup of the conglomerate. To examine changes in the diversification discount around spinoffs, we compute excess values for the three fiscal years preceding the sample spinoffs and the three years following the spinoffs. Similar to Rajan et al. (2000), we compute excess value as the difference between the value of the firm and its imputed value. Imputed values are calculated as the salesweighted sum of the ratio of market value-to-sales for single-segment firms in the same industry. Specifically, the pre-spinoff excess value of the firm is defined as

$$
E V_{s}=\left(\frac{M V}{S}\right)_{d}-\sum_{j=1}^{n}\left(\frac{M V}{S}\right)_{j}^{s s} \frac{S_{j}}{S},
$$

where $(M V / S)_{d}$ is the market value of a diversified firm divided by sales of the firm, such that market value $(M V)$ of a firm is the book value of assets plus the market value of common equity minus the sum of the book value of common equity and balance sheet deferred tax, $S_{j}$ is the end-of-the-year sales of segment $j(j=1$ to $n)$, where $n$ is the number of segments within a diversified firm, $S$ is the sum of the endof-the-year segment sales, and $(M V / S)_{j}^{s s}$ is the median market-to-sales ratio of single-segment firms in the same industry as segment $j$. Industry is defined at the 
three-digit SIC level provided that there are at least five single-segment firms in the industry. If there are fewer than five single-segment firms in a three-digit SIC industry, we define industry at the two-digit SIC level. We also report asset-based excess values.

Following the spinoff, we compute excess values using the combined values of the remaining parent firm and the spunoff unit(s). The post-spinoff excess value is the sum of the market value of the parent and the spunoff unit divided by the sum of the sales of the parent and the spunoff unit minus the imputed market-to-sales ratio. In other words, we compute the excess value of the firm as if the spinoff had not occurred. Specifically, post-spinoff excess values are calculated as

$$
E V_{s}=\left(\frac{\sum_{i=1}^{m} M V_{i}}{T S}\right)_{d}-\sum_{j=1}^{n+k}\left(\frac{M V}{S}\right)_{j}^{s s} \frac{S_{j}}{T S}
$$

where $[i=1]$ represents the parent firm and $i=2$ to $m$ represents the spunoff units, $n$ is the number of segments in the parent firm and $k$ is the number of segments in the spunoff units, $(n+k)$ is the total number of segments existing after the spinoff, $(\Sigma M V / T S)_{d}$ is the combined market value of the parent and the spunoff unit(s) divided by the combined sales of the parent and the spunoff unit(s), TS is the total sales of the parent and the spunoff firms, $(M V / S)_{j}^{s s}$ is the median market-to-sales ratio of single-segment firms in the same industry of segment $j$, and $S_{j}$ is the end-ofthe-year sales of segment $j(j=1$ to $n+k)$.

Table 3 reports excess values for the three years preceding the spinoff announcement (years -3 to -1 ) and the three years following completion of the spinoff (years +1 to +3 ). We exclude the period between the announcement of the spinoff and its completion to avoid the confounding influence of the stock price reaction to the spinoff announcement. The median length of time between spinoff announcement and completion is seven months. In some cases, therefore, the spinoff announcement and completion occur in different fiscal years. In these cases, there are two fiscal years between year -1 and year +1 .

Consistent with the diversification literature, we find that prior to the spinoff, the sample firms trade at a substantial discount relative to their single-segment peers. The average (median) excess value is $-0.32(-0.19)$ using the sales-based measure and $-0.12(-0.14)$ using the asset-based measure. All average and median excess values are significant at the 0.01 level in the year prior to the spinoff announcement. The sample firms exhibit a substantial discount in each of the three years preceding the spinoff announcement and exhibit a slight, though statistically insignificant, decline in excess value between years -3 and -1 .

Our average excess values using the sales-based measure are lower than those reported in Rajan et al. (2000). Rajan et al. (2000) report average excess values of -0.11 vs. -0.32 in our sample. Although the lower excess values in our sample are consistent with a sample selection bias towards diversified firms having less efficient investment policies, median excess values are quite similar, -0.19 vs. -0.18 . Moreover, excess values using an asset-based measure are also quite similar. Rajan 
Table 3

Excess values surrounding spinoffs

Mean [median] excess values for the sample of 106 spinoffs completed by multisegment firms from 1981 to 1996. Excess value is measured using the method of Rajan et al. (2000). $E V_{s}$ is the market-to-sales ratio of the spinoff firm minus the sales-weighted sum of the median market-to-sales ratio of industry matched single segment firms. $E V_{B A}$ is the market-to-book ratio of the sample firm minus the asset-weighted sum of the median market-to-book of industry matched single segment firms. Industry is defined at the three-digit SIC level, provided that there are at least five single-segment firms in the industry. If not, we define industry at the two-digit SIC level. Excess value of the post-spinoff combined entity is calculated by treating the parent and the spunoff unit as a combined entity. Excess values are winsorized at the 5th and 95th percentiles. $*, * *$, and $* * *$ indicate statistical significance at the $10 \%, 5 \%$, and $1 \%$ levels, respectively.

\begin{tabular}{|c|c|c|c|c|c|c|}
\hline & \multicolumn{3}{|c|}{ Pre-spinoff } & \multicolumn{3}{|c|}{ Post-spinoff } \\
\hline & -3 & -2 & -1 & 1 & 2 & 3 \\
\hline$E V_{s}$ & $\begin{array}{l}-0.2927^{* * *} \\
{[-0.1133]^{* *}}\end{array}$ & $\begin{array}{r}-0.2469^{* * *} \\
{[-0.1803]^{* * *}}\end{array}$ & $\begin{array}{r}-0.3159^{* * *} \\
{[-0.1873]^{* * *}}\end{array}$ & $\begin{array}{c}0.0530 \\
{[0.1141]}\end{array}$ & $\begin{array}{c}0.0375 \\
{[0.0572]}\end{array}$ & $\begin{array}{r}-0.0694 \\
{[-0.0452]}\end{array}$ \\
\hline$E V_{B A}$ & $\begin{array}{r}-0.0917^{*} \\
{[-0.1539]^{* *}}\end{array}$ & $\begin{array}{r}-0.1017^{* *} \\
{[-0.1154]^{* * *}}\end{array}$ & $\begin{array}{r}-0.1187^{* * *} \\
{[-0.1385]^{* * *}}\end{array}$ & $\begin{array}{l}-0.0166 \\
{[-0.0331]}\end{array}$ & $\begin{array}{l}-0.0012 \\
{[-0.0146]}\end{array}$ & $\begin{array}{r}-0.0330 \\
{[0.0239]}\end{array}$ \\
\hline$N$ & 92 & 101 & 99 & 87 & 78 & 67 \\
\hline
\end{tabular}

et al. (2000) report mean (median) excess values of $-0.12(-0.16)$ vs. $-0.12(-0.14)$ in our sample.

Following completion of the spinoff, the diversification discount is eliminated. The average (median) excess value in the year following the spinoff is $0.05(0.11)$ using the sales-based measure and $-0.02(-0.03)$ using the asset-based measure. None of the excess values in the post-spinoff period are significantly different from zero. Moreover, the change in excess value from the pre-spinoff to the post-spinoff period is significant at the 0.01 level (not reported in the table).

The large change in excess value from year -1 to year +1 appears, at first, to be at odds with the relatively small stock price reaction to the spinoff announcement. However, to the extent that the market anticipates some type of restructuring, a large part of the spinoff's valuation impact will be impounded in the firm's stock price prior to the announcement of the spinoff. Moreover, the sample firms may exhibit excess returns between the announcement and the completion of the spinoff, reflecting the resolution of uncertainty about the completion of the spinoff. Consistent with these conjectures, we find that cumulative market-adjusted returns average $11.1 \%$ between the end of year -1 and the completion of the spinoff. We also find that cumulative market-adjusted returns average $6.0 \%(\mathrm{t}$-statistic $=1.62)$ between the completion of the spinoff and the end of year $+1 .^{3}$

\footnotetext{
${ }^{3}$ See Cusatis et al. (1993), Desai and Jain (1999), and McConnell et al. (2001) for further evidence on post-spinoff abnormal stock returns.
} 
The findings in Table 3 are consistent with the view that diversified firms destroy value and that this value is recouped when the conglomerate breaks up via a spinoff. Graham et al. (2002) argue that a portion of the discount for diversified firms stems from the firms purchasing lower-valued firms. Similarly, Campa and Kedia (1999) and Hyland (1999) argue that diversified firms trade at a discount before they are diversified. These arguments suggest that the diversification discount is a byproduct of endogenous self-selection. A similar argument for spinoffs is that firms increase their excess value because they spin off their low-valued divisions. Note, however, that our methodology precludes this explanation because we examine the combined value of the parent and the spunoff unit. In other words, we hold constant the composition of the assets and examine whether they are valued differently once they are split up.

We also examine, but do not report in the tables, excess values of the 44 singlesegment companies that undertake spinoffs. We find only weak evidence that these companies exhibit negative excess values prior to the spinoff, and no evidence of a significant change in excess value following the spinoff. At first glance, this result appears to be at odds with our earlier observation that announcements of spinoffs by single-segment companies are met with a stock price reaction that is slightly higher than that for multisegment companies. However, it turns out that the number of observations for single-segment companies falls from 42 in year -1 to 17 in year +3 . This decline in observations is substantially greater than that observed in the multisegment companies (see Table 3). Further analysis reveals that takeovers are primarily responsible for the missing observations. Of the 25 companies that disappear between year -1 and year +3 , either the parent or the spunoff unit are acquired in 18 cases. We conclude, therefore, that the higher stock price reaction to the announcement of spinoffs of single-segment companies is likely due to the higher rate of takeover in this subset of companies.

\section{Changes in investment allocations}

The inefficient investment hypothesis predicts that diversification destroys value by distorting investment decisions. Hence, the efficiency of investment allocations improves following the break up of a diversified firm. In this section, we directly examine this hypothesis by analyzing changes in investment allocations following spinoffs. We first examine investment at the individual segment level, then analyze firm-level measures of investment efficiency.

\subsection{Industry-adjusted levels of investment in segments}

Previous studies of conglomerates show that diversified firms invest differently than their stand-alone peers. In particular, Lamont (1997) and Shin and Stulz (1998) show that investment levels in individual segments are related to the cash flows produced by other business segments within the diversified firm. This crosssubsidization could be efficient if it allows a financially constrained firm to channel 
additional resources into its high-growth divisions. However, Shin and Stulz (1998), Scharfstein (1998), and Rajan et al. (2000) show that the opposite is true: diversified firms appear to invest too much in their low- $q$ divisions and too little in their high- $q$ divisions.

In Table 4, we examine investment levels in individual segments in the three years preceding each sample spinoff and the three years following the spinoff. We report three different measures of investment: (i) unadjusted investment, defined as the ratio of segment capital expenditures to segment sales, (ii) industry-adjusted investment, defined as the segment's capital expenditure-to-sales ratio minus the median capital expenditure-to-sales ratio of single-segment firms in the same three-digit SIC industry (if there are not at least five single-segment firms in the industry, we define industry at the two-digit level), and (iii) industry and firm-adjusted investment, defined as the segment's industry-adjusted investment minus the firm's salesweighted sum of industry-adjusted investment.

We partition individual segments according to whether they are high-Tobin's $q$ or low-Tobin's $q$ segments. We use the median $q$ of single-segment firms operating in the same three-digit SIC industry as a proxy for the $q$ of the individual segment, where $q$ is measured using the method proposed in Badrinath and Lewellen (1997). High- $q$ segments are defined as those for which the segment's $q$ is greater than the sales-weighted average $q$ of all segments in the firm. Similarly, low- $q$ segments are those for which the segment's $q$ is less than or equal to the sales-weighted average $q$ of all segments in the firm. (We obtain qualitatively similar results if we define high and low $q$ relative to the median $q$ for all business segments rather than relative to the average $q$ within the firm.) As we did with excess values, we compare investment levels in the pre-spinoff period with those in the post-spinoff period by treating the spunoff unit as one of the firm's segments in the post-spinoff period. We report means and medians, but focus most of our discussion on medians because the means are influenced by outliers.

Panel A of Table 4 indicates that the sample firms invest at a marginally higher rate in their high- $q$ segments than in their low- $q$ segments prior to the spinoff. The median ratio of capital expenditures to sales is 0.0438 for low- $q$ segments and 0.0467 for high- $q$ segments. Following the spinoff, investment rates are increased slightly for both high- $q$ and low- $q$ segments.

Of greater interest is the comparison of investment rates with those of singlesegment firms operating in the same industry. This analysis is reported in Panel B of Table 4. The results in Panel B show that the sample firms invest at a lower rate than their single-segment peers prior to the spinoff. The median industry-adjusted ratio of capital expenditures to sales is -0.0039 prior to the spinoff and is significant at the 0.05 level. Interestingly, this lower rate of investment is confined to the high- $q$ segments, where median industry-adjusted investment rates are -0.0089 . This corresponds to high $q$ segments investing $16 \%(0.0089 /(0.0089+0.0467))$ less than their single-segment counterparts. By contrast, prior to the spinoff, median industryadjusted investment rates are statistically indistinguishable from zero in the low- $q$ segments. 
Table 4

Segment-level investment rates surrounding spinoffs

Investment is measured as the ratio of segment capital expenditures to segment sales. We report unadjusted, industry-adjusted, and industry-and-firm-adjusted investment rates. Industry-adjusted investment is equal to the ratio of capital expenditures to sales for the segment minus the same ratio for the median single-segment firm operating in the same three-digit SIC industry. Industry-and-firmadjusted investment is equal to industry-adjusted investment minus the sales-weighted sum of industryadjusted investment for the whole firm. The pre-spinoff period includes the three years preceding the spinoff announcement. The post-spinoff period includes the three years following completion of the spinoff. Individual segments are divided into high- $q$ and low- $q$ groups, based on whether the industry median $q$ for the segment is greater than the sales-weighted average $q$ for the firm. Mean investment rates are reported with medians in brackets below. Statistical significance of investment rates is estimated using $t$-tests for means and the Wilcoxon signed ranks test for medians. Significance of differences across groups is measured using an $F$-statistic for means and $\chi^{2}$-test for medians. All final variables are winsorized at the 1 st and 99th percentiles. $*, * *$, and $* * *$ indicate statistical significance at the $10 \%, 5 \%$, and $1 \%$ levels, respectively. The sample includes 106 spinoffs of diversified firms between 1981 and 1996.

\begin{tabular}{|c|c|c|c|c|c|}
\hline & $N$ & Pre-spinoff & $N$ & Post-spinoff & $F\left[\chi^{2}\right]$ \\
\hline \multicolumn{6}{|c|}{ Panel A. Capital expenditures/sales } \\
\hline Total & 989 & $\begin{array}{c}0.1140 * * * \\
{[0.0446]^{* * *}}\end{array}$ & 807 & $\begin{array}{c}0.1548^{* * *} \\
{[0.0507]^{* * *}}\end{array}$ & $\begin{array}{l}8.73^{* * * *} \\
{[3.92]^{* *}}\end{array}$ \\
\hline Low- $q$ & 513 & $\begin{array}{c}0.0935^{* * * *} \\
{[0.0438]^{* * *}}\end{array}$ & 413 & $\begin{array}{c}0.1145^{* * *} \\
{[0.0477]^{* * *}}\end{array}$ & $\begin{array}{c}2.35 \\
{[2.14]}\end{array}$ \\
\hline High- $q$ & 476 & $\begin{array}{c}0.1360^{* * *} \\
{[0.0467]^{* * *}}\end{array}$ & 394 & $\begin{array}{c}0.1971^{* * *} \\
{[0.0523]^{* * *}}\end{array}$ & $\begin{array}{l}6.29^{* *} \\
{[1.74]}\end{array}$ \\
\hline$F$ & & $11.29^{* * *}$ & & $9.95^{* * *}$ & \\
\hline$\left[\chi^{2}\right]$ & & {$[4.11]^{* *}$} & & {$[3.28]^{*}$} & \\
\hline \multicolumn{6}{|c|}{ Panel B. Industry-adjusted capital expenditures/sales } \\
\hline Total & 989 & $\begin{array}{c}0.0101^{* *} \\
{[-0.0039]^{* *}}\end{array}$ & 807 & $\begin{array}{r}0.0649^{* * *} \\
{[-0.0005]^{* *}}\end{array}$ & $\begin{array}{l}21.30^{* * * *} \\
{[8.67]^{* * *}}\end{array}$ \\
\hline Low- $q$ & 513 & $\begin{array}{c}0.0119^{* *} \\
{[-0.0000]}\end{array}$ & 413 & $\begin{array}{c}0.0372^{* * *} \\
{[-0.0011]}\end{array}$ & $\begin{array}{l}4.69^{* *} \\
{[0.32]}\end{array}$ \\
\hline High- $q$ & 476 & $\begin{array}{c}0.0081 \\
{[-0.0089]^{* * *}}\end{array}$ & 394 & $\begin{array}{c}0.0940^{* * *} \\
{[-0.0004]}\end{array}$ & $\begin{array}{c}16.60^{* * *} \\
{[12.36]^{* * *}}\end{array}$ \\
\hline $\begin{array}{l}F \\
{\left[\chi^{2}\right]}\end{array}$ & & $\begin{array}{c}0.14 \\
{[15.21]^{* * *}}\end{array}$ & & $\begin{array}{l}5.98^{* *} \\
{[0.06]}\end{array}$ & \\
\hline \multicolumn{6}{|c|}{ Panel C. Industry-and firm-adjusted capital expenditures/sales } \\
\hline Total & 989 & $\begin{array}{c}0.0160^{* * *} \\
{[0.0017]^{*}}\end{array}$ & 807 & $\begin{array}{l}0.0541^{* * *} \\
{[0.0001]^{*}}\end{array}$ & $\begin{array}{l}10.48^{* * * *} \\
{[0.04]}\end{array}$ \\
\hline Low- $q$ & 513 & $\begin{array}{c}0.0213^{* * *} \\
{[0.0060]^{* * *}}\end{array}$ & 413 & $\begin{array}{c}0.0296^{* *} \\
{[0.0011]^{* *}}\end{array}$ & $\begin{array}{c}0.46 \\
{[3.18]^{*}}\end{array}$ \\
\hline High- $q$ & 476 & $\begin{array}{c}0.0103 \\
{[-0.0052]^{* *}}\end{array}$ & 394 & $\begin{array}{c}0.0799^{* * *} \\
{[-0.0005]}\end{array}$ & $\begin{array}{l}11.58^{* * *} \\
{[4.39]^{* *}}\end{array}$ \\
\hline $\begin{array}{l}F \\
{\left[\chi^{2}\right]}\end{array}$ & & $\begin{array}{c}1.45 \\
{[26.41]^{* * *}}\end{array}$ & & $\begin{array}{l}4.57^{* *} \\
{[0.85]}\end{array}$ & \\
\hline
\end{tabular}


Following the spinoff, there is a significant increase in industry-adjusted investment in the high- $q$ segments. Median industry-adjusted investment increases from -0.0089 to -0.0004 . By contrast, there is no change in industry-adjusted investment in low- $q$ segments. Following the spinoff, both high- $q$ and low- $q$ segments invest at median rates that are statistically indistinguishable from that of the single-segment firms operating in the same industry. The average industry-adjusted investment rate of high- $q$ segments is greater than that of low- $q$ segments in the post-spinoff period. However, the average values are driven by a few outliers.

Because we aggregate segments cross-sectionally in Panel B, it is possible that our findings are due to differences in financial resources across firms. To the extent that high- $q$ segments come disproportionately from firms with low financial resources, this will bias our results towards finding that high- $q$ segments underinvest relative to their single-segment industry peers. To address this concern, Panel $\mathrm{C}$ of Table 4 reports industry-and-firm-adjusted investment levels. The results in Panel $\mathrm{C}$ show that, prior to the spinoff, the sample firms allocate funds disproportionately to the low- $q$ segments. The median industry and firm-adjusted investment rate is significantly positive for low- $q$ segments and significantly negative for high- $q$ segments. The difference between high- $q$ and low- $q$ segments is significant at the 0.01 level. Following the spinoff, there is a significant reduction in the median industry and firm-adjusted investment of low- $q$ firms and a significant increase for high- $q$ firms.

The results in Table 4 indicate a substantial change in investment allocations following the sample spinoffs. Prior to the spinoff, the sample firms allocate investment funds in a manner similar to that reported in large-sample studies of diversified firms. That is, the sample firms fail to give priority to their high- $q$ segments in the capital allocation process. The net result is that the firms invest less in the high- $q$ segments than do their single-segment industry peers. By contrast, investment in low- $q$ segments is on par with that of single-segment firms in the same low- $q$ industries. Following the spinoff, investment in high- $q$ segments is significantly increased to the point that these segments no longer underinvest relative to their single-segment industry peers.

\subsection{Firm-level measures of investment efficiency}

Although informative, the cross-sectional evidence on investment allocations in individual segments does not address the overall efficiency of investment allocations at the firm level. To address this issue, we compute two measures of overall investment efficiency, the relative investment ratio (RINV) and the relative value added by allocation (RVA), as proposed by Rajan et al. (2000).

RINV is defined as the sales-weighted sum of firm-and industry-adjusted investment in high- $q$ segments minus the sales-weighted sum of firm and industryadjusted investment in low- $q$ segments. More precisely, 
Relative Investment Ratio (RINV)
$=\frac{\sum_{j=1}^{k} S_{j}\left(\frac{I_{j}}{S_{j}}-\left(\frac{I}{S}\right)_{j}^{s S}-\sum_{j=1}^{n} w_{j}\left(\frac{I_{j}}{S_{j}}-\left(\frac{I}{S}\right)_{j}^{s S}\right)\right)-\sum_{j=n-k+1}^{n} S_{j}\left(\frac{I_{j}}{S_{j}}-\left(\frac{I}{S}\right)_{j}^{s S}-\sum_{j=1}^{n} w_{j}\left(\frac{I_{j}}{S_{j}}-\left(\frac{I}{S}\right)_{j}^{s S}\right)\right)}{T S}$

where $S_{j}$ is the sales of segment $j, w_{j}$ is the sales of segment $j$ divided by the firm's total sales, $I_{j}$ is the capital expenditures of segment $j,(I / S)_{j}^{s s}$ is the capital expenditure-to-sales ratio of the median single-segment firm operating in the same three-digit SIC industry as firm $j$, and $T S$ is the total sales of the firm. For $j=1 \ldots k$, the firm's segments have an industry median $q$ greater than the firm's sales-weighted average $q$, while $j=(n-k+1) \ldots n$ indicates that the firm's segments have an industry median $q$ less than the firm's sales-weighted average $q$. Positive values for RINV indicate that the firm is investing relatively more in its high- $q$ segments.

To compute RVA, we weight firm and industry-adjusted segment investment by the difference between the industry median Tobin's $q$ for that segment and the salesweighted average $q$ for the firm. More precisely,

Relative Value Added by Allocation ( $R V A)$

$$
=\frac{\sum_{j=1}^{n} S_{j}\left(q_{j}-\bar{q}\right)\left(\frac{I_{j}}{S_{j}}-\left(\frac{I}{S}\right)_{j}^{s s}-\sum_{j=1}^{n} w_{j}\left(\frac{I_{j}}{S_{j}}-\left(\frac{I}{S}\right)_{j}^{s S}\right)\right)}{T S},
$$

where $q_{j}$ is the median Tobin's $q$ for single-segment firms operating in the same threedigit SIC code as the given segment and $\bar{q}$ is the sales-weighted average $q$ of the firm. If the industry median $q$ is a good proxy for the marginal $q$ of segment investment, RVA can be viewed as a measure of the overall value added (subtracted) by the firm's investment allocation process.

Table 5 reports mean and median values for RINV and RVA over the three years preceding the spinoff announcement (years -3 to -1 ) and the three years following completion of the spinoff years $(+1$ to +3$)$. As before, we treat the spunoff unit as if it is still one of the divisions of the parent firm in the post-spinoff period.

The data indicate that both RINV and RVA are significantly negative in the year prior to the spinoff announcement. This indicates that, prior to the spinoff, the sample firms allocate relatively more capital to segments with lower growth opportunities and that this incrementally reduces firm value. Following the spinoff, there is no evidence of inefficient investment allocation. Both RINV and RVA are statistically insignificant in the post-spinoff period. Moreover, there is a significant increase in the measures of investment efficiency from the pre-spinoff period to the post-spinoff period. Average RINV increases from -0.0106 to 0.0055 between year -1 and year +1 . Similarly, average RVA increases from -0.0032 to 0.0002 . These changes are significant at the 0.01 level (not reported in the table).

The findings in Table 5 support the view that spinoffs are associated with a significant increase in the efficiency of the investment allocation process. An alternative possibility, however, is that there is an unexpected improvement in the growth opportunities of the high- $q$ divisions that is not captured by the $q$ of the single-segment industry peers. Firms optimally respond to this shock by increasing 
Table 5

Firm-level measures of investment efficiency surrounding spinoffs

Firm-level measures of investment efficiency for the three years preceding the announcement of the spinoff (years -3 to -1 ) and the three years following completion of the spinoff (years +1 to +3 ). The sample includes 106 spinoffs completed by diversified firms between 1981 and 1996. RINV is defined as the salesweighted sum of firm-and industry-adjusted investment in high- $q$ segments minus the sales-weighted sum of firm-and industry-adjusted investment in low- $q$ segments. To compute RVA, we weight firm-andindustry-adjusted segment investment by the difference between the industry median Tobin's $q$ for that segment and the sales-weighted average $q$ for the firm. Post-spinoff parent companies and spunoff units are combined as if they are still part of the same company. Means are reported with medians in brackets below. Statistical significance of mean and median values is tested using a $t$-test and the Wilcoxon signed rank test, respectively. All final variables are winsorized at the 5th and 95th percentiles. *, **, and $* * *$ indicate statistically significant at the $10 \%, 5 \%$, and $1 \%$ levels, respectively.

\begin{tabular}{|c|c|c|c|c|c|c|}
\hline & \multicolumn{3}{|c|}{ Year relative to spinoff announcement } & \multicolumn{3}{|c|}{ Year relative to spinoff completion } \\
\hline & -3 & -2 & -1 & +1 & +2 & +3 \\
\hline RINV & $\begin{array}{c}-0.0019 \\
{[-0.0032]}\end{array}$ & $\begin{array}{l}-0.0070^{* *} \\
{[-0.0028]^{*}}\end{array}$ & $\begin{array}{c}-0.0106^{* * *} \\
{[-0.0071]^{* * *}}\end{array}$ & $\begin{array}{c}0.0055 \\
{[0.0009]}\end{array}$ & $\begin{array}{c}0.0025 \\
{[-0.0012]}\end{array}$ & $\begin{array}{c}0.0066 \\
{[0.0042]}\end{array}$ \\
\hline RVA & $\begin{array}{c}-0.0013 \\
{[-0.0005]^{*}}\end{array}$ & $\begin{array}{c}-0.0020^{* *} \\
{[-0.0004]^{* *}}\end{array}$ & $\begin{array}{c}-0.0032^{* * *} \\
{[-0.0008]^{* * *}}\end{array}$ & $\begin{array}{c}0.0002 \\
{[0.0000]}\end{array}$ & $\begin{array}{c}-0.0000 \\
{[-0.0004]}\end{array}$ & $\begin{array}{c}0.0004 \\
{[0.0003]}\end{array}$ \\
\hline$N$ & 98 & 105 & 102 & 88 & 79 & 67 \\
\hline
\end{tabular}

investment in the higher- $q$ divisions, which in turn leads to an increase in the measure of excess value. We provide direct evidence on this possibility by examining the profitability of high- $q$ segments over the three years following completion of the spinoff. Contrary to the hypothesis, we find no evidence of an increase in profitability for high $-q$ segments between years -1 and +3 . If anything, the profitability of high- $q$ segments declines, both in an absolute sense and relative to industry peers. This undermines the view that our findings are a spurious byproduct of an unexpected improvement in the prospects of high- $q$ segments. We conclude, therefore, that the sample firms invest inefficiently prior to the spinoff and that this inefficiency is curtailed following the spinoff.

The data in Table 5 also show a significant decline in overall investment efficiency in the three years leading up to the spinoff announcement. This finding suggests the possibility that a decline in investment efficiency is one motivation for the spinoff. The decline in investment efficiency is also consistent with the view that the sample is biased towards diversified firms that encounter problems in the years preceding the spinoff. To further investigate this view, we examine the performance of the sample firms over years -3 to -1 . We find no significant changes in the ratio of EBITDA-tosales EBITDA-to-assets, Tobin's $q$, interest coverage, the ratio of total debt to the book value of assets, and the ratio of total debt to the market value of capital. (These results are not reported in a table.) We thus conclude that the sample firms do not exhibit a deterioration in performance over the three years prior to the spinoff. 
It is also possible that the decline in RVA and RINV over years -3 to -1 is due to the sample firms being relatively undiversified in year -3 , then becoming more diversified prior to the spinoff. We find no evidence that this is the case, however. The number of industries and number of segments in which the firm operates does not change, on average, between years -3 and -1 . Moreover, we do not observe any significant change in either the standard deviation of the median industry $q$ 's across firm segments or the range of industry median $q$ 's.

Finally, we observe from Table 5 that 21 firms disappear from the sample between year +1 and +3 . Of these, 13 are lost because the spunoff unit (eight cases), the parent (four cases), or both (one case) are acquired. In six cases, observations are missing because we lack some of the required data. In one case the spunoff unit is liquidated and in another case the parent goes bankrupt. It is possible, therefore, that the changes in investment efficiency that we document are driven by cases in which the company is preparing a unit for sale.

To explore this possibility further, we divide the sample companies into quartiles on the basis of the change in RVA or RINV between years -1 and +1 . We then examine the proportion of observations that remain in each quartile as of year +3 . This analysis reveals that the proportion of firms remaining independent is nearly identical across the quartiles. We conclude, therefore, that the significant changes in RVA and RINV are not driven by cases in which the sample companies are preparing a business unit for sale.

In Table 6, we examine the correlation between the range of segment $q$ values in year -1 and the subsequent change in investment efficiency following the spinoff. Specifically, we divide the sample firms into quartiles based on the range of industry $q$ values for the firm's segments in year -1 . We then compare measures of investment efficiency and post-spinoff changes in these measures across the quartiles. The results indicate that firms in the quartile with the highest dispersion in segment $q$ values exhibit the lowest RVA and RINV in year -1 , and exhibit the largest changes in RVA and RINV between years -1 and +1 . Interestingly, those firms in the quartile with the lowest dispersion of segment $q$ values exhibit no evidence of investment inefficiency prior to the spinoff and no evidence of a change in RVA or RINV following the spinoff. We interpret these findings as consistent with the prediction in Rajan et al. (2000) that investment inefficiencies are more likely in firms with a wide dispersion in segment investment opportunities. Moreover, these findings further suggest that factors other than changes in investment efficiency are driving the gains from spinoffs in some firms.

We find a similar correlation between the $q$ of the highest $q$ segment and the change in RVA (RINV). That is, firms whose highest $q$ segment is in the top quartile of all sample firms exhibit significantly higher changes in RVA (RINV) than firms whose highest $q$ segment is in the lowest quartile. These findings raise the question of whether it is the dispersion of $q$ or the level of $q$ that matters the most. Unfortunately, we are not able to answer this question definitively because the correlation between the $q$ of the highest $q$ segment and the range of $q$ is 0.86 . 
Table 6

Dispersion in segment $q$ values and changes in investment efficiency

Measures of investment efficiency and changes in these measures across quartiles formed on the basis of the range of segment $q$ values within the firm in year -1 . To compute RVA, we weight firm-and-industryadjusted segment investment by the difference between the industry median Tobin's $q$ for that segment and the sales-weighted average $q$ for the firm. RINV is defined as the sales-weighted sum of firm-and industryadjusted investment in high- $q$ segments minus the sales-weighted sum of firm-and industry-adjusted investment in low- $q$ segments. Post-spinoff parent companies and spunoff units are combined as if they are still part of the same company. Changes in RVA and RINV are measured between years -1 and +1 relative to the spinoff. Means are reported with medians in brackets below. The sample includes 106 spinoffs of diversified firms between 1981 and 1996.*,**, and $* * *$ indicate statistical significance at the $10 \%, 5 \%$, and $1 \%$ levels, respectively.

\begin{tabular}{lccccc}
\hline & $N$ & $R V A-1$ & $\Delta R V A$ & $R I N V-1$ & $\Delta R I N V$ \\
\hline $\begin{array}{l}\text { Quartile 1 } \\
\text { (highest) }\end{array}$ & 17 & $-0.0218^{* * *}$ & $0.0166^{* *}$ & $-0.0351^{* * *}$ & $0.0294^{* *}$ \\
& & {$[-0.0098]^{* * *}$} & {$[0.0072]^{* * *}$} & {$[-0.0255]^{* * *}$} & {$[0.0198]^{*}$} \\
Quartile 2 & 22 & $\begin{array}{c}-0.0059 \\
{[-0.0026]^{*}}\end{array}$ & $\begin{array}{c}0.0066 \\
{[0.0010]}\end{array}$ & -0.0166 & $0.0287^{* *}$ \\
& & & {$[-0.0143]$} & {$[0.0178]^{* *}$} \\
Quartile 3 & 19 & $-0.0019^{*}$ & 0.0045 & $-0.0121^{*}$ & $0.0260^{*}$ \\
& & {$[-0.0010]^{* *}$} & {$[0.0012]$} & {$[-0.0072]^{* *}$} & {$[0.0126]^{* *}$} \\
Quartile 4 (lowest) & 18 & -0.0000 & 0.0013 & -0.0018 & 0.0163 \\
& & {$[-0.0002]$} & {$[-0.0002]$} & {$[-0.0034]$} & {$[0.0044]$} \\
$F$ & & $5.29^{* * *}$ & $2.64^{*}$ & 1.42 & 0.22 \\
{$\left[\chi^{2}\right]$} & & {$[20.38]^{* *}$} & {$[7.48]^{*}$} & {$[8.18]^{* *}$} & {$[1.14]$} \\
\hline
\end{tabular}

\subsection{Is industry q a good proxy for marginal $q$ of segment investment?}

The marginal $q$ of new investment can differ substantially from a firm's (or an industry's) average $q$. Because our analysis and conclusions depend on the assumption that the industry median $q$ is a good proxy for the marginal $q$ of segment investment, we evaluate this assumption in two ways. First, we compare the profitability of segments from high- $q$ industries with that of segments from low- $q$ industries. Second, we define high-growth segments on the basis of industry investment rather than industry Tobin's $q$.

Although not necessarily the case, it is likely that segments with higher marginal $q$ will exhibit higher current profitability as well. To test this conjecture, we compare the ratio of operating income to sales for high-growth segments (as defined by industry Tobin's $q$ ) with that for low-growth segments in the year prior to the spinoff (year -1 ). In untabulated results, we find that operating profitability is significantly higher in high-industry- $q$ segments. The median ratio of operating income to sales is 0.1005 for high- $q$ segments and 0.0827 for low- $q$ segments. The difference is significant at the 0.01 level. These findings are consistent with the view 
that the marginal $q$ of high-industry- $q$ segments exceeds that of low-industry- $q$ segments.

As a further robustness test, we define a segment as high growth if the industry median ratio of capital expenditures to sales for single-segment firms exceeds the sales-weighted average of the industry median ratio of capital expenditures to sales for the entire firm. The logic for this definition of high growth is that if other firms in the industry are investing heavily, it is presumably because investment opportunities are good in that industry. ${ }^{4}$ Using this alternative definition, we then recalculate our investment efficiency measure, RINV (RVA no longer has the same meaning.) We find that the median RINV in years -3 through -1 is $-0.0047,-0.0054$, and -0.0047 , respectively. All are statistically significant at the 0.01 level. Similar to our prior findings, the median RINV increases to a statistically insignificant -0.0018 in the first year following the spinoff. The change from year -1 to year +1 is significant at the 0.01 level. We thus conclude that our findings do not depend on the use of industry median $q$ as a proxy for the marginal $q$ of segment investment.

\section{The relation between changes in excess value and changes in investment allocations}

Up to this point, our findings indicate that spinoffs are associated with significant increases in excess value and significant changes in the capital allocation process. Although our measures of investment efficiency are suggestive, they do not clearly establish a link between the changes in value and the changes in capital allocations. In fact, it is possible that the changes in investment allocation are actually valuereducing. As Rajan et al. (2000) point out, one could argue that diversified firms exist, in part, to allocate resources differently than do markets. Suppose that segment-level investment opportunities differ from those of the median singlesegment firm in the industry. In such a case, corporate headquarters of a diversified firm should allocate capital differently from the manner implied by the $q$-ratios of single-segment firms in the industry. Once a spinoff takes place and the internal capital market is dismantled, no such internal transfers of capital are possible. Hence, the change in capital allocation that we document following spinoffs might actually represent a cost to spinoffs that is offset against other benefits from spinoffs.

To address this issue, Table 7 reports estimates of ordinary least squares (OLS) regressions of the change in excess value on the change in our measures of investment efficiency. We measure changes from the fiscal year prior to the announcement of the spinoff (year -1 ) through the fiscal year following completion of the spinoff (year +1 ). Models (1)-(3) employ relative value added (RVA) as the measure of investment efficiency, while Models (4)-(6) employ the relative investment ratio (RINV) as the measure of efficiency. In unreported regressions, we also estimate OLS regressions of excess value on RVA in the year prior to the spinoff announcement. Similar to Rajan et al. (2000), we find a significant positive relation between the pre-spinoff excess value and RVA. This supports the idea that RVA is a

${ }^{4}$ Gertner et al. (2002) conduct a similar test. 
Table 7

The relation between the change in excess value and the change in investment efficiency

Estimates from ordinary least squares regressions of the change in excess value on the change in investment efficiency. Excess value is the market-to-sales ratio of the spinoff firm minus the sales-weighted sum of the median market-to-sales ratio of industry matched single segment firms. Changes are measured from the fiscal year ending prior to the spinoff announcement through the fiscal year following the completion of the spinoff. The relative investment ratio (RINV) is defined as the sales-weighted sum of firm-and industry-adjusted investment in high- $q$ segments minus the sales-weighted sum of firm-and industry-adjusted investment in low- $q$ segments. To compute RVA, we weight firm-and-industry-adjusted segment investment by the difference between the industry median Tobin's $q$ for that segment and the sales-weighted average $q$ for the firm. Post-spinoff parent companies and spunoff units are combined as if they are still part of the same company. The change in investment $(\triangle T I N D I N V)$ is the change in the industry-adjusted ratio of capital expenditures to sales for the firm as a whole. The change in operating cash flow $(\triangle D F C F S)$ is the change in industry-adjusted operating income to sales for the firm as a whole. Linverse $q$ is the change in the inverse of the firm's sales-weighted Tobin's $q$. The change in firm size $(\Delta$ Size $)$ is the square root of the change in the firm's sales. All variables are winsorized at the 5th and 95 th percentiles. We also include (but do not report in the table) firm dummy variables. The sample includes 106 spinoffs completed by diversified firms between 1981 and 1996. Coefficient estimates are reported with t-statistics in parentheses below. *,**, and $* * *$ indicate significance of the $F$-statistic at the $10 \%, 5 \%$, and $1 \%$ levels, respectively.

\begin{tabular}{|c|c|c|c|c|c|c|}
\hline Independent variables & (1) & (2) & (3) & (4) & (5) & (6) \\
\hline Intercept & $\begin{array}{c}0.375 \\
(1.55)\end{array}$ & $\begin{array}{c}0.369 \\
(1.51)\end{array}$ & $\begin{array}{c}0.393 \\
(1.55)\end{array}$ & $\begin{array}{c}0.416 \\
(1.59)\end{array}$ & $\begin{array}{c}0.418 \\
(1.58)\end{array}$ & $\begin{array}{c}0.445 \\
(1.64)\end{array}$ \\
\hline$\Delta R V A$ & $\begin{array}{l}37.805 \\
(6.56)\end{array}$ & $\begin{array}{l}36.709 \\
(6.41)\end{array}$ & $\begin{array}{l}35.000 \\
(5.26)\end{array}$ & & & \\
\hline$\Delta R I N V$ & & & & $\begin{array}{c}10.821 \\
(5.14)\end{array}$ & $\begin{array}{l}10.627 \\
(4.20)\end{array}$ & $\begin{array}{r}9.917 \\
(3.85)\end{array}$ \\
\hline$\triangle T I N D I N V$ & & $\begin{array}{r}0.657 \\
(0.40)\end{array}$ & $\begin{array}{r}0.233 \\
(0.14)\end{array}$ & & $\begin{array}{c}-0.346 \\
(-0.23)\end{array}$ & $\begin{array}{c}-1.004 \\
(-0.49)\end{array}$ \\
\hline$\triangle \mathrm{DFCFS}$ & $\begin{array}{r}0.077 \\
(0.05)\end{array}$ & $\begin{array}{r}0.030 \\
(0.02)\end{array}$ & $\begin{array}{l}-0.280 \\
(-0.16)\end{array}$ & $\begin{array}{c}0.446 \\
(0.25)\end{array}$ & $\begin{array}{c}0.484 \\
(0.27)\end{array}$ & $\begin{array}{l}-0.002 \\
(-0.00)\end{array}$ \\
\hline$\Delta$ Inverse $\mathrm{q}$ & & & $\begin{array}{c}0.968 \\
(1.06)\end{array}$ & & & $\begin{array}{r}1.411 \\
(1.45)\end{array}$ \\
\hline$\Delta$ Size & & & $\begin{array}{c}0.164 \\
(0.40)\end{array}$ & & & $\begin{array}{c}0.274 \\
(0.62)\end{array}$ \\
\hline Adjusted $R^{2}$ & 0.352 & 0.345 & 0.337 & 0.243 & 0.233 & 0.236 \\
\hline$F$-statistic & $14.60^{* * *}$ & $10.86^{* * *}$ & $7.35^{* * *}$ & $9.03^{* * *}$ & $6.69^{* * *}$ & $4.86^{* * *}$ \\
\hline$N$ & 76 & 76 & 76 & 76 & 76 & 76 \\
\hline
\end{tabular}


reasonable measure of the incremental value associated with the firm's investment allocation process.

Model (1) of Table 7 reports a significant positive relation between the change in excess value and the change in RVA. While this finding supports a causal link between the change in investment policy and the change in value, it could be a spurious byproduct of changes in either financial resources or in firm-specific growth opportunities. To control for this possibility, Model (2) includes the change in the industry-adjusted ratio of operating income-to-sales and the change in the industryadjusted ratio of capital expenditures-to-sales. As shown in Model (2), the inclusion of these variables attenuates the coefficient on RVA slightly, but the coefficient remains significant at the 0.01 level. We also estimate, but do not report in the table, models in which we calculate the change in operating income over years -1 to +3 . This reduces the sample size for the regressions from 76 to 58 , but the results are qualitatively identical.

Another possibility is that the positive relation between excess value and RVA is a spurious byproduct of the presence of Tobin's $q$ on both sides of the equation. Our measure of excess value is essentially an industry-adjusted Tobin's $q$. Moreover, RVA is calculated by weighting industry-adjusted investment for each segment by the deviation between the estimate of segment $q$ and the sales-weighted average $q$ for the firm. Following Rajan et al. (2000), we control for this possibility by including the change in the inverse of Tobin's $q$ as an independent variable in Model (3). In this model, we also control for firm size using the change in the square root of the firm's sales. As shown in Model (3), the inclusion of these additional variables has no meaningful impact on the coefficient of RVA. The positive relation between the change in excess value and the change in RVA remains significant at the 0.01 level.

Models (4)-(6) repeat these tests after replacing RVA with RINV as the measure of investment efficiency. Note that, unlike RVA, RINV is not subject to the criticism that Tobin's $q$ is present on both sides of the regression equation. The results are qualitatively identical. The change in excess value from the year before the spinoff's announcement to the year following completion of the spinoff is positively related to the change in the relative investment ratio.

We can use the regression coefficients to estimate the economic importance of the changes in investment policy. Specifically, we multiply the coefficient on RVA in Model (3) (35.0) times the average (median) change in RVA, 0.0070 (0.0012). This results in an implied change in excess value of $0.245(0.042)$, or approximately $52 \%$ $(25 \%)$ of the average (median) change in excess value for the sample. Similarly, if we multiply the coefficient on RINV in Model (6) (9.9) times the average (median) change in RINV, $0.0253(0.0130)$, we get an implied change in excess value of 0.233 $(0.129)$, or approximately $49 \%(74 \%)$ of the average (median) change in excess value.

An alternative approach is to estimate median (as opposed to OLS) regressions, then multiply those coefficients times the median changes in RVA and RINV. Using this alternative approach, we find that the median changes in RVA (RINV) explain $19 \%(64 \%)$ of the median change in excess value. These results are not reported in a table. We conclude, therefore, that the changes in investment policy are economically 
important, but are unlikely to account for the entire change in value associated with the sample spinoffs.

We conduct two additional robustness tests. First, because we estimate crosssectional regressions, we introduce the possibility of heteroskedasticity. White's (1980) heteroskedasticity-consistent standard errors could be used, but they are only asymptotically consistent. Their small sample properties are unknown. Therefore, we estimate standard errors using a bootstrapping procedure involving 10,000 replications of our sample. Our inferences are unchanged. For example, the tstatistic on the change in RVA in Model (3) falls from 5.26 to 3.73, but is still statistically significant at the 0.01 level.

Second, we estimate a nonparametric kernel regression of the change in excess value on the change in RVA. The advantage of this approach is that it allows for a visual inspection of the empirical relation between changes in excess value and changes in RVA without constraining that relation to be linear. The fitted values from the regression are plotted in Fig. $1 .^{5}$ The results show a fairly smooth positive relation between the change in excess value and the change in RVA. The curve is relatively flat when the change in RVA is negative, but is strongly positively sloped when the change in RVA is positive. We thus conclude that changes in investment allocations following spinoffs are associated with significant increases in firm value.

\section{Discussion and related evidence}

Our findings contribute to separate literatures that attempt to explain the discount associated with diversification and the shareholder gains associated with corporate spinoffs. In this section we discuss the implications of our findings for these literatures and introduce some unresolved issues.

\subsection{The diversification discount}

As discussed in the introduction, the discount associated with corporate diversification has two broad interpretations. One interpretation is that diversification destroys value. Alternatively, however, diversification and value may be endogenously related. That is, either lower-valued firms choose to diversify or firms diversify by purchasing lower-valued firms. To date, the evidence does not convincingly support either interpretation.

Our findings provide further evidence on the debate over whether there is a causal link between diversification and value. The fact that we observe significant changes in investment policy following the spinoff is consistent with the view that diversification per se leads to less efficient investment allocations. In this sense, our findings broadly support the theoretical models of Scharfstein and Stein (2000)

\footnotetext{
${ }^{5}$ The kernel density is estimated using the Epanechnikov density. The unknown nonlinear function is estimated using the Nadaraya-Watson approximation and the optimal bandwidth is selected using the method of cross-validation. For further details, see Campbell et al. (1997, Chapter 12).
} 


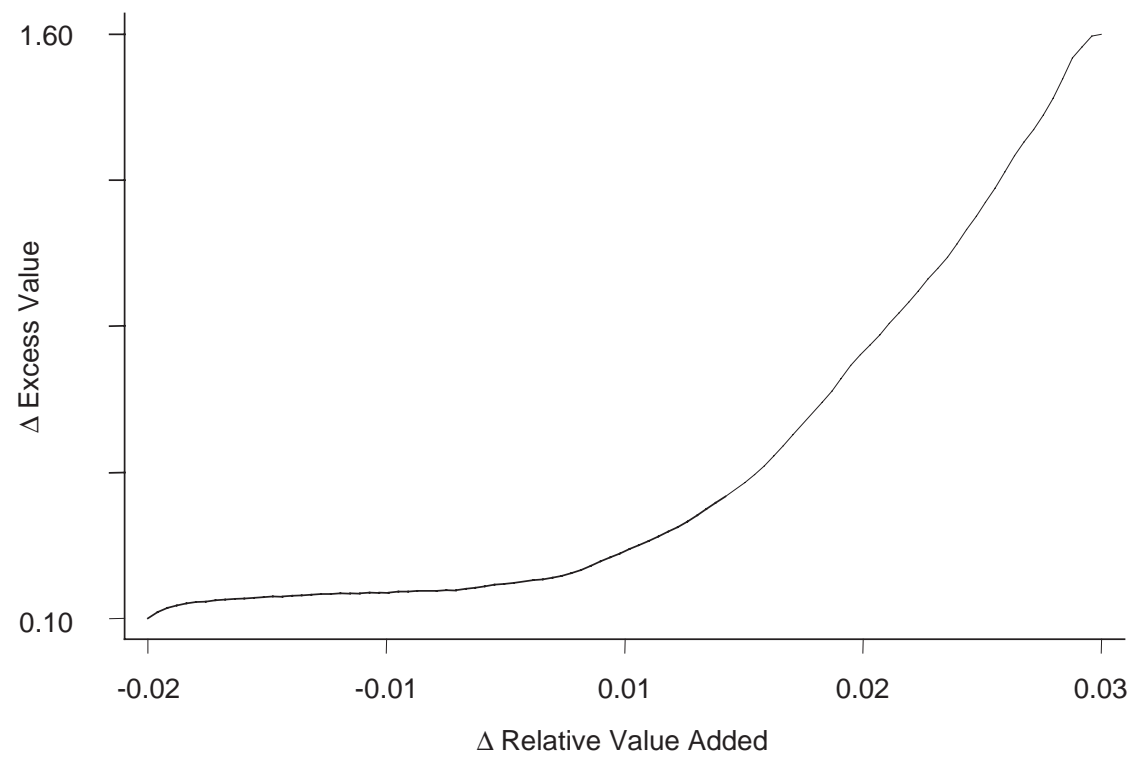

Fig. 1. Nonparametric kernel regression of change in excess value $(\Delta E V)$ on the change in relative value added $(\Delta R V A)$ from Year -1 to Year +1 . The figure represents a plot of the fitted values from a kernel regression of $\Delta E V$ against $\triangle R V A$ over years -1 to +1 . Excess value is the market-to-sales ratio of the spinoff firm minus the sales-weighted sum of the median market-to-sales ratio of industry matched single segment firms. To compute RVA, we weight firm-and-industry-adjusted segment investment by the difference between the industry median Tobin's $q$ for that segment and the sales-weighted average $q$ for the firm. The $y$-axis is the fitted values from the kernel regression and the $x$-axis is the corresponding 100 grid points of $\triangle R V A$. The kernel density is estimated with the Epanechnikov kernel. Bandwidth is selected using a generalized cross validation function that employs the Nadaraya-Watson approximation. To avoid the influence of extreme observations, the extreme one percent of the data are excluded from the estimation.

and Rajan et al. (2000). Moreover, the fact that changes in investment allocations are significantly related to changes in value around the spinoff suggests that the lower value of diversified firms cannot be completely explained by endogenous firm choices. Lamont and Polk (2002) arrive at a similar conclusion by studying exogenous changes in diversity in a sample of diversified firms. Burch and Nanda (2003) study the relationship between changes in value and changes in the diversity of growth opportunities following spinoffs and also conclude that the diversification discount cannot be explained solely by selection bias or measurement error.

Nonetheless, an important caveat to the interpretation of our findings is the sample selection bias mentioned in Section 2. Because our sample consists of firms that have undertaken a corporate spinoff, it is arguably biased towards firms that have inefficient investment policies. As a result, it would be inappropriate to generalize our findings to the population of diversified firms. The most that we can say is that for some firms, the diversification discount appears to be caused by inefficient investment. 


\subsection{Gains from corporate spinoffs}

A large number of studies have documented positive stock price reactions to the announcement of corporate spinoffs. Our results indicate that an important source of value in corporate spinoffs is an improvement in the allocation of capital. In this sense, our study extends the spinoff literature by providing direct evidence on a specific source of value. It is worth noting that an improvement in investment efficiency is consistent with the findings of several of the spinoff studies cited in the Introduction. Our findings fit particularly well with those of Allen et al. (1995), who find evidence consistent with the hypothesis that the gains from spinoffs represent the re-creation of wealth lost when the division was originally acquired. The changes in investment allocations that we document provide an explanation for why value is lost when the division is acquired and why it is recaptured when the division is spun off. Similarly, as discussed below, our findings provide one possible explanation for why enhanced corporate focus and reduced information asymmetry are associated with the gains from spinoffs.

Consistent with our findings, the results of three other contemporaneous working papers point to changes in investment allocations as a source of gains from the breakup of conglomerates. Gertner et al. (2002) examine changes in investment allocations in divisions that are spun off and report that investment in the division is more sensitive to investment opportunities (as measured by industry $q$ ) following the spinoff. We extend Gertner et al. (2002) by examining changes in investment allocations in the combined (parent + spunoff unit) firm and by relating these changes to changes in excess value.

Dittmar and Shivdasani (2003) examine how the divestiture of a division affects investment in the parent firm's remaining divisions. Like us, they find that increased investment in underinvesting segments is associated with a reduction in the diversification discount. Because they examine divestitures, however, it is unclear whether their findings are due to an improved allocation of capital across divisions or to the proceeds from the divestiture relaxing an external financial constraint. Moreover, they are unable to examine changes in investment allocations in the divested unit.

Finally, McNeil and Moore (2001) report a positive relation between spinoff announcement returns and a measure of pre-spinoff investment efficiency. They infer that spinoffs create value by dismantling inefficient internal capital markets. Our tests provide direct evidence on this issue and support McNeil and Moore's (2001) inference.

\subsection{Why do capital allocations change following spinoffs?}

The models of Rajan et al. (2000) and Scharfstein and Stein (2000) predict that diversified firms will invest inefficiently, with investment in low- $q$ divisions being subsidized by reduced investment in high- $q$ divisions. By extension, these models predict a reduction in this inefficient cross-subsidization following a spinoff, 
resulting in increased investment in the high- $q$ divisions and decreased investment in low- $q$ divisions.

Our results are only partially consistent with these predictions. Although we do find evidence of inefficient investment prior to the spinoff, we find little evidence of overinvestment in low- $q$ divisions. These divisions invest at a rate that is statistically indistinguishable from that of their single-segment industry peers. The apparent inefficiency comes from below-normal investment in the firm's high- $q$ divisions. Following the spinoff, investment in low- $q$ divisions does not change, but investment in high- $q$ divisions increases. The fact that there is a net increase in industry-adjusted investment suggests that a simple cross-subsidization story is incomplete. While our results are not inconsistent with resources being diverted from high- $q$ to low- $q$ divisions in the pre-spinoff period, they are inconsistent with the specific prediction that there is overinvestment in low- $q$ divisions that comes from underinvestment in high- $q$ divisions. It appears as if there are binding financial constraints in the prespinoff period that are mitigated following the spinoff.

In theory, a spinoff could relax financial constraints in two ways. First, as argued in Krishnaswami and Subramaniam (1999), spinoffs reduce information asymmetry by separating the divisions of a firm into individually operated and traded entities. This allows the divisions with superior growth opportunities to raise external capital on more attractive terms. Consistent with this hypothesis, Krishnaswami and Subramaniam (1999) find that among firms completing spinoffs, the frequency of equity issues increases significantly in the two years following a spinoff. However, the magnitude of this effect seems too small to fully explain our findings. Of the 118 firms in their sample, $20(17 \%)$ issue equity in the two years preceding the spinoff, while $30(25 \%)$ issue equity in the two years following the spinoff.

A second possibility is that a spinoff relaxes financial constraints by allowing the separate divisions to choose financial policies that are more suitable for their growth opportunities. Theories of optimal capital structure and dividend policy argue that the firm's financial policies influence investment policy through their impact on discretionary cash flow. For example, Stulz (1990) shows that increased debt reduces the cost of overinvestment, but increases the probability of underinvestment. The optimal debt ratio reflects a tradeoff between these two agency costs of managerial discretion. As a consequence, the optimal debt ratio will be negatively related to growth opportunities. Similarly, Easterbrook (1984) and Rozeff (1982) argue that the optimal dividend policy is a function of growth opportunities. Low-growth firms should pay high dividends because they do not have profitable uses for the cash. High-growth firms should pay low dividends so as to avoid constraining the firm from investing in profitable opportunities.

In theory, diversified firms will choose leverage and dividend policies based on the growth opportunities of the firm as a whole. However, because the firm's growth opportunities are likely to be driven by the growth opportunities of the firm's larger, core segment, it is likely that the firm's financial policies will be more suitable for the firm's core segment than for its non-core segments. Nonetheless, Lang et al. (1996) find that the negative relation between leverage and investment is just as strong for non-core segments as it is for core segments. This suggests that the firm's leverage 
constrains investment in all of the firm's segments, regardless of growth opportunities. In other words, managers do not appear to apportion debt service requirements across segments according to their respective growth opportunities. This can result in underinvestment in those segments that have higher growth opportunities. Similar arguments can be made regarding the firm's dividend policy. One explanation for this dynamic is that debt service (and dividend service) of individual segments is influenced by internal power struggles of the type modeled by Rajan et al. (2000) and Scharfstein and Stein (2000).

One might argue that if the firm's financial policies are overly restrictive, the firm could simply choose to have lower leverage or lower dividend payouts. However, by doing so, the firm would be increasing the costs of overinvestment in lower- $q$ divisions. By spinning off a segment, the separate divisions of the firm can choose financial policies that are more suitable for their own level of growth opportunities, thereby mitigating underinvestment problems. While a full treatment of this hypothesis is beyond the scope of this paper, our findings for high- $q$ segments are broadly consistent with a relaxation of financial constraints in these divisions.

\section{Conclusions}

We study investment allocations in firms completing corporate spinoffs. Consistent with large-sample studies of diversified firms, spinoff firms are valued at a discount relative to a portfolio of single-segment industry peers in the year prior to the spinoff. Following the spinoff, the combination of the parent and spunoff unit is no longer valued at a discount. Our evidence points to changes in investment allocations as an explanation for the change in value. Prior to the spinoff, the sample firms fail to give preference to high- $q$ segments in the capital allocation process. This inefficiency in the investment allocation process is remedied following the spinoff. Moreover, the change in investment allocation is significantly associated with the change in value surrounding the spinoff. We conclude that the sample spinoffs create value by improving the investment allocation process. Further work is needed to identify the precise channel(s) through which capital allocations are improved.

\section{References}

Allen, J.W., McConnell, J.J., 1998. Equity carve-outs and managerial discretion. Journal of Finance 53, $163-186$.

Allen, J.W., Lummer, S.L., McConnell, J.J., Reed, D.K., 1995. Can takeover losses explain spinoff gains? Journal of Financial and Quantitative Analysis 30, 465-485.

Aron, D.J., 1991. Using the capital market as a monitor: corporate spinoffs in an agency framework. Rand Journal of Economics 22, 505-518.

Badrinath, S.G., Lewellen, W.G., 1997. On the measurement of Tobin's q. Journal of Financial Economics 44, 77-122.

Berger, P., Ofek, E., 1995. Diversification's effect on firm value. Journal of Financial Economics 37, 39-65. 
Burch, T.R., Nanda, V., 2003. Divisional diversity and the conglomerate discount: the evidence from spinoffs. Journal of Financial Economics, (in press).

Campa, J.M., Kedia, S., 1999. Explaining the diversification discount. Working paper, Harvard University.

Campbell, J.Y., Lo, A.W., Mackinlay, A.C., 1997. The Econometrics of Financial Markets. Princeton University Press, New Jersey.

Chevalier, J.A., 2000. What do we know about cross-subsidization? Evidence form the investment policies of merging firms. Working paper, University of Chicago and NBER.

Comment, R., Jarrell, G.A., 1995. Corporate focus and stock returns. Journal of Financial Economics 37 , 67-87.

Cusatis, P.J., Miles, J.A., Woolridge, J.R., 1993. Restructuring through spinoffs: the stock market evidence. Journal of Financial Economics 33, 293-311.

Daley, L., Mehrotra, V., Sivakumar, R., 1997. Corporate focus and value creation: evidence from spinoffs. Journal of Financial Economics 45, 257-281.

Desai, H., Jain, P.C., 1999. Firm performance and focus: long-run stock market performance following spinoffs. Journal of Financial Economics 54, 75-101.

Dittmar, A., Shivdasani, A., 2003. Divestitures and divisional investment policies. Journal of Finance, forthcoming.

Easterbrook, F.H., 1984. Two agency-cost explanations of dividends. American Economic Review 74, 650-659.

Gertner, R., Powers, E., Scharfstein, D., 2002. Learning about internal capital markets from corporate spinoffs. Journal of Finance 57, 2479-2506.

Gilson, S.C., Healy, P.M., Noe, C.F., Palepu, K.G., 1997. Information effects of spinoffs, equity carveouts, and targeted stock offerings. Working paper, Harvard University.

Graham, J.R., Lemmon, M.L., Wolf, J., 2002. Does corporate diversification destroy value? Journal of Finance 57, 695-720.

Hite, G.L., Owers, J.E., 1983. Security price reactions around corporate spinoff announcements. Journal of Financial Economics 12, 409-436.

Hyland, D., 1999. Why do firms diversify? An empirical examination. Working paper, University of Texas Arlington.

John, K., Ofek, E., 1995. Asset sales and increase in focus. Journal of Financial Economics 37 , $105-126$.

Krishnaswami, S., Subramaniam, V., 1999. Information asymmetry, valuation, and the corporate spinoff decision. Journal of Financial Economics 53, 73-112.

Lamont, O., 1997. Cash flow and investment: evidence from internal capital market. Journal of Finance 52, 83-109.

Lamont, O., Polk, C., 2002. Does diversification destroy value? Evidence from industry shocks. Journal of Financial Economics 63, 51-77.

Lang, L., Stulz, R.M., 1994. Tobin's q, corporate diversification, and firm performance. Journal of Political Economy 102, 1248-1280.

Lang, L., Poulsen, A., Stulz, R.M., 1994. Asset sales, firm performance, and the agency costs of managerial discretion. Journal of Financial Economics 37, 3-37.

Lang, L., Ofek, E., Stulz, R.M., 1996. Leverage, investment, and firm growth. Journal of Financial Economics 40, 3-29.

Lins, K., Servaes, H., 1999. International evidence on the value of corporate diversification. Journal of Finance 54, 2215-2239.

Maksimovic, V., Phillips, G., 2002. Do conglomerate firms allocate resources inefficiently across industries? Journal of Finance 57, 721-768.

McConnell, J.J., Ozbilgin, M., Wahal, S., 2001. Spinoffs, ex ante. Journal of Business 74, 245-280.

McNeil, C.R., Moore, W.T., 2001. Spinoff wealth effects and the dismantling of internal capital markets. Working paper, University of South Carolina.

Miles, J.A., Rosenfeld, J.D., 1983. The effects of voluntary spinoff announcements on shareholder wealth. Journal of Finance 38, 1597-1606.

Palia, D., Ye, J., 2002. Diversification and managerial compensation. Working paper, Rutgers University. 
Parrino, R., 1997. Spinoffs and wealth transfers: the Marriott case. Journal of Financial Economics 43, 241-274.

Rajan, R., Servaes, H., Zingales, L., 2000. The cost of diversity: the diversification discount and inefficient investment. Journal of Finance 55, 35-80.

Rozeff, M.S., 1982. Growth, beta, and agency costs as determinants of dividend payout ratios. Journal of Financial Research 5, 249-259.

Scharfstein, D.S., 1998. The dark side of internal capital markets II: evidence from diversified conglomerates. Working paper, NBER.

Scharfstein, D.S., Stein, J.C., 2000. The dark side of internal capital markets: divisional rent-seeking and inefficient investment. Journal of Finance 55, 2537-2564.

Schipper, K., Smith, A., 1983. Effects of recontracting on shareholder wealth: the case of voluntary spinoffs. Journal of Financial Economics 12, 437-467.

Servaes, H., 1996. The value of diversification during the conglomerate merger wave. Journal of Finance 51, 1201-1225.

Shin, H., Stulz, R.M., 1998. Are internal capital markets efficient? Quarterly Journal of Economics 113, 531-552.

Stulz, R., 1990. Managerial discretion and optimal financing policies. Journal of Financial Economics 26, $3-27$.

Vijh, A.M., 1994. The spinoff and merger ex-date effects. Journal of Finance 49, 581-609.

White, H., 1980. A heteroscedasticity-consistent covariance matrix estimator and a direct test for heteroscedasticity. Econometrica 48, 817-838.

Whited, T.M., 2001. Is it inefficient investment that causes the diversification discount? Journal of Finance $56,1667-1692$. 